\title{
Elaboration Of Sor Paradigm Using Information Transparency And Curiosity Variables Approach To Purchase Intention
}

\author{
Irantha Hendrika Kenang1) \\ irantha.hendrika@ciputra.ac.id \\ Junko Alesandro' ${ }^{2)}$ \\ junko.Alesandro@ciputra.ac.id \\ Alexander Marfin Sutanto Putra ${ }^{3)}$ \\ amarfin@student.ciputra.ac.id
}

1) 2) 3)Faculty of Management and Business, Ciputra University Surabaya

\begin{abstract}
:
This study uses S-O-R theory to determine the effect of Information Transparency and Curiosity on the Purchase Intention of the Comme business. This research is a quantitative research. Primary data is collected using questionnaires. The sampling technique uses purposive sampling with a total of 100 respondents. The results showed that Information Transparency has a significant effect on Curiosity and Curiosity has a significant effect on Purchase Intention. Based on the results of this study, the Comme business is expected to be able to consider the quality and quantity of information shared on Instagram which can affect consumer affection such as curiosity and thus increase consumer purchase interest.
\end{abstract}

Keywords: Information Transparency, Curiosity, Purchase Intention 


\section{INTRODUCTION}

Creative economy growth in Indonesia is inseparable from its relationship with the millennial generation and the development of technology. APJII noted that internet users reached more than 196.7 million and most are the millennial generation (APJII, 2020). Millennials are also often referred to as the driving factor for the Indonesian economy, especially in the creative economy sector. One rapidly growing sector of the creative economy is the food and beverage (culinary) industry where growth was recorded at 8.67 percent throughout 2018. According to the presentation of the Indonesian Ministry of Industry, the business potential of this industry will continue to grow consistently, requiring entrepreneurs to continue innovating in order to increase competitiveness and contribute optimally in this sector (Ministry of Trade and Indonesia, 2019).

Seeing this occuring phenomenon, businesspeople in the culinary industry are also increasingly utilising technology to attract millennials. One of the methods used is to maximize the function of social media. The survey results from APJII (2020) stated that the first reason people use the internet is social media. One of the most used social media platforms in Indonesia is Instagram. Instagram is now used by businesses as a medium to communicate and promote their products. Various features on Instagram, such as sharing photos and videos, hashtags, comments, like buttons, direct messages, and so on provide access for companies or consumers to interact and convey messages or information to encourage intentions to buy the products offered (Huey \& Yazdanifard, 2014; Celik, 2017).

In previous researches, it was stated that social media is now a new stimulus for consumers that can lead to a person's desire to gain new knowledge as well as the emergence of cognitive desires and sensory experiences as well as sensory curiosity, which then results in exploratory behavior as a form of response (Lee, Strong, Kahn, and Wang, 2002; Voorveld, Noort, Muntinga \& Bronner, 2018; Widodo, Yusiana \& Aqmarina, 2019; Reio, 2019). Thus, this research will use the SOR (Stimulus-Organism-Response) theoretical approach to see whether the stimulus, in this case is Information Transparency in social media (Instagram), affects the organism, namely the Curiosity of target consumers (Curiosity), and thus leads to a response, in this case is Purchase Intention, on a startup business, namely Comme, which is engaged in the food and beverage industry and uses social media, especially Instagram, in communicating and marketing its products.

\section{LITERATURE REVIEW}

\section{S-O-R Theory}

The SOR theory was discovered by a psychologist Hovland in 1953 (Jackob \& Huess, 2015). He stated that the theory of SOR in the communication process focuses on how to communicate. The SOR communication model is divided into 3 parts, namely Stimulus, Organism, and Response. In 1974, Mehrabian and Russel also put forward this theory in the study of environmental psychology. SOR theory gradually extended to the field of consumer psychology. This theory explains the importance of the relationship between emotions and consumer behavior. Stimulus refers to the environmental influence that stimulates an individual so that an 
emotion called an organism emerges as the result. These emotions then affect the attitude or behavioral response of the communicant.

\section{INFORMATION TRANSPARENCY}

In the previous explanation it was said that social media is now a new stimulus for targeted consumers. In a study conducted by Nunthiphatprueksa \& Suntrayuth (2018), it was stated that transparency of information is very important on social media because it can significantly affect the cognitive and affective dimensions of consumers. The definition of information transparency itself according to Zhu (2004) is the level of availability and accessibility of information to its participants. Williams (2015) stated that the definition of information transparency can be divided into three features, which are: relevance, timeliness, and reliability of information. Nunthiphatprueksa \& Suntrayuth (2018) stated that information on social media must be relevant, comprehensible, and the message delivery must welltimed. Information must also be up to date and not over-displayed. According to research, one of the reasons consumers abandon purchases on social media is due to a lack of information transparency. Therefore, it is important for businesspeople to significantly pay attention to information transparency related to product transparency, vendor transparency, and transaction transparency (Zhou, 2018).

\section{CURIOSITY}

According to Reio (2019), curiosity can be defined as the desire to gain new knowledge (cognitive curiosity) and sensory experience (sensory curiosity) which then results in exploratory behavior (consulting, observing, thinking, and experimenting). A person's curiosity and exploration can encourage someone to take risks, in the sense that because they do not know or are not sure sure about something, then they are finally willing to try it. Curiosity is also important because it can develop into interest. Curiosity as an initial sensation then develops into interest, which is more durable in nature. When interest has been formed, an individual tends to seek deeper information, for a longer period of time, and at a higher intensity.

According to Kashdan, Mcknight, and Disabato (2018), curiosity has an important position in the study of motivation, emotion, cognition, and others. Researchers argue that curiosity exists in 5 dimensions, including:

- Happy Exploration

- Deprivation Sensitivity

- Stress Tolerance

- Social Curiosity

- Seeking Sensation

\section{PURCHASE INTENTION}

Research conducted by Hui (2017) stated that purchase interest can be used as a predictor of consumer purchasing behavior. Purchase intention is the subjective possibility that the consumer would perform a certain behavior. If a consumer has an interest or desire to acquire a product or service, he or she will state that there is 
hope of buying in their mind. Frambach, Roest, \& Krishnan (2007) suggested that consumers seek comments about products online during the pre-purchase stage, they also share their opinions in positive and negative ways about their product experience in the postpaid stage. Kim \& Lennon (2008) stated that purchase intention refers to the behavior that consumers anticipate regarding their future purchasing decisions. Demand for a product may be caused by a number of online opinions generated from social media. Kim \& Youn (2019) also stated that when consumer knowledge is high, buying interest increases. One of the ways to increase consumer awareness is by providing transparent information. The following are several indicators measuring purchase intention (Hui, 2017):

- Transactional interest, when consumers are interested in making purchases on a product

- Referential interest, when consumers tend to want to provide references or recommend a product to other consumers

- Preferential interest, when consumers are interested in making a product the first choice in shopping activities

- Explorative interest, when consumers are interested in finding out more about a purchased product

\section{Relationship between Information Transparency and Curiosity}

In research conducted by Nunthiphatprueksa \& Suntrayuth (2018) on SOR in the context of tourism, transparency of information as a stimulus that consumers get when searching for information on social media is an important part of planning. When the information provided is of high quality and transparency, there will be a sense of curiosity about the intended tourist destination. Consumers will search for deeper information regarding the tourist destination and images of the tourist destination. Xiang and Gretzel (2010) also revealed that the transparency of information from social media is considered by consumers to be more comprehensive. The content and quality of information on social media can ultimately attract consumers' attention and create consumer curiosity about a product.

\section{H1: Information Transparency has a significant effect on Curiosity}

\section{Relationship between Curiosity and Purchase Intention}

Nunthiphatprueksa \& Suntrayuth (2018) stated that consumer curiosity on the images of a tourist destination has an impact on interest in visiting these tourist destinations. The consumer's curiosity obtained from previous tourist reviews has also increased consumer interest in traveling. This is in line with a previous research conducted by Wang \& Wang (2012) which stated that the quality of information transparency that has been felt by consumers through testimonials creates consumer curiosity and thus they are motivated to make purchases of these products or services. Patanasiri and Krairit (2019) also concluded that there was a significant influence between curiosity and purchase intention on their research results. Based on these data, the following hypothesis is formulated:

H2: Curiosity has a significant effect on Purchase Intention 


\section{RESEARCH METHODS}

This study uses primary data collected through a questionnaire. The measurement scale used is a Likert scale. The Likert scale is a scale that can be used to measure a person's attitude, opinion, and perception about an object or phenomenon (Albaum, 1997). Total sample of this study are 100 respondents. The selected respondents are students in several universities in Surabaya whose age is included in the millennial generation and those who have buying power and are actively using social media, especially Instagram. Surabaya is also considered as having one of the highest number of internet users in Indonesia. Secondary data are taken from scientific journals, articles, and publication data relevant to the research. Data analysis techniques include validity and reliability tests, the coefficient of determination (R Square) and the $t$ test for hypothesis testing.

\section{RESEARCH MODEL}

This study examines the effect of Information Transparency (Stimulus) on Curiosity (Organism) and the effect of Curiosity (Organism) on Purchase Intention (Response). Hypothesis testing uses the structural equation modeling (SEM) method with the Partial Least Square-SEM (PLS-SEM) approach. The following is the research conceptual framework:

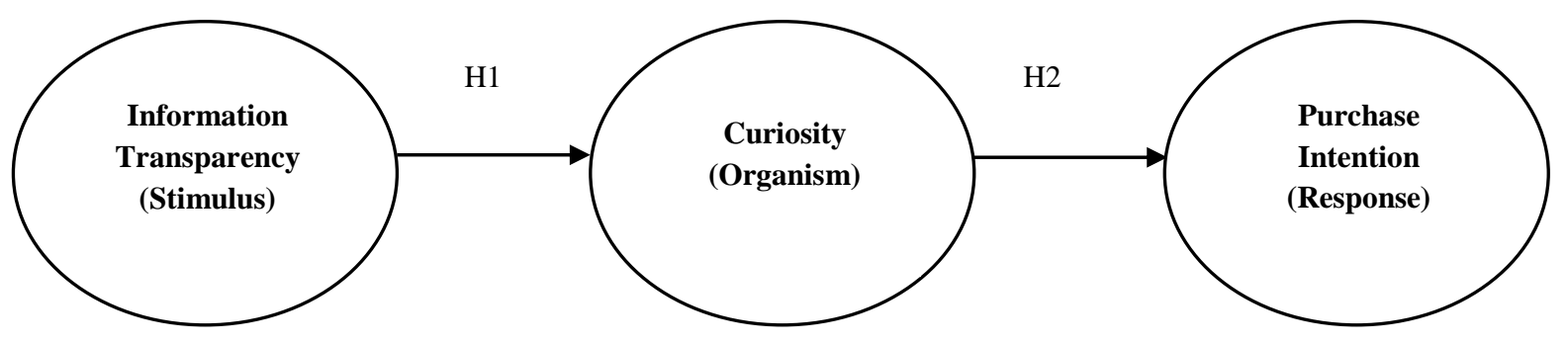

Figure 1. Analysis Model

Source: Processed by researchers (2020)

\section{RESULTS AND DISCUSSION \\ Validity $\mathcal{E}$ Reliability}

Validity testing in this study was carried out by looking at the AVE (Average Variance Extracted) and Discriminant Validity values. An indicator can be said to have good validity, if it has an AVE value of $>0.50$ (Hair Jr. et al., 2014). Meanwhile, the measurement for Discriminant Validity uses cross loading of the indicator. If the measurement of the construct cross loading is greater than 0.7 and greater than the other cross loading values, then it is considered valid (Abdillah, 2015). This study has 3 constructs (information transparency, curiosity, and purchase intention) with 12 indicators. However, after testing the validity, several indicators were found to be invalid and thus eliminated. The indicators in question are indicators $\mathrm{X} 1$ and $\mathrm{X} 4$ on the information transparency construct, $\mathrm{Y} 1.4$ on the Curiosity construct and indicators Y2.2 and Y2.4 on the purchase intention 
construct. The following are the results of the validity test after the indicators mentioned above were eliminated:

\begin{tabular}{|c|c|c|c|}
\hline Variable & Indicator & $\begin{array}{l}\text { Outer } \\
\text { Loading }\end{array}$ & AVE \\
\hline \multirow{2}{*}{$\begin{array}{c}\text { Information } \\
\text { Transparency }\end{array}$} & $\mathrm{X} 2$ & 0.863593 & 0.767436 \\
\cline { 2 - 3 } & $\mathrm{X} 3$ & 0.888301 & \\
\cline { 2 - 3 } Curiosity & $\mathrm{Y} 1.1$ & 0.811525 & \multirow{2}{*}{0.743050} \\
\cline { 2 - 3 } & $\mathrm{Y} 1.2$ & 0.872299 & \\
\cline { 2 - 3 } & $\mathrm{Y} 1.3$ & 0.851138 & \\
\hline Purchase & $\mathrm{Y} 2.1$ & 0.750552 & 0.714102 \\
\cline { 2 - 3 } Intention & $\mathrm{Y} 2.3$ & 0.960610 & \\
\hline
\end{tabular}

Table 1 Outer Loading and AVE

Source: Researcher Processed Data (2020)

\begin{tabular}{|c|c|c|c|}
\hline $\begin{array}{c}\text { Indicato } \\
\mathrm{r}\end{array}$ & $\begin{array}{c}\text { Information } \\
\text { Transparency }\end{array}$ & Curiosity & Purchase Intention \\
\hline $\mathrm{X} 2$ & 0.863593 & 0.077462 & 0.323879 \\
\hline $\mathrm{X} 3$ & 0.888301 & 0.085037 & 0.272147 \\
\hline $\mathrm{Y} 1.1$ & 0.023991 & 0.811525 & 0.135545 \\
\hline $\mathrm{Y} 1.2$ & 0.072699 & 0.872299 & 0.189899 \\
\hline $\mathrm{Y} 1.3$ & 0.108239 & 0.851138 & 0.113926 \\
\hline $\mathrm{Y} 2.1$ & 0.464232 & 0.091467 & 0.750552 \\
\hline $\mathrm{Y} 2.3$ & 0.236932 & 0.217500 & 0.960610 \\
\hline
\end{tabular}

Table 2 Cross Loading

Source: Researcher Processed Data (2020)

For reliability testing, a variable is declared consistent if it has a composite reliability value of $>0.7$. The table below shows that all variable indicators have met the reliability test.

\begin{tabular}{|l|l|}
\hline Variable & Composite Reliability \\
\hline Information Transparency & 0.868395 \\
\hline Curiosity & 0.882216 \\
\hline Purchase Intention & 0.850696 \\
\hline
\end{tabular}

Table 3 Composite Reliability

Source: Researcher Processed Data (2020)

\section{DETERMINATION COEFFICIENT TEST (R Square)}

The R Square test is performed to determine the proportion or percentage of total variation in endogenous variables explained by exogenous variables. The higher the R Square value, the better the variable model (Ghozali \& Fuad, 2014). The following are the results of the R Square test: 


\begin{tabular}{|l|l|}
\hline Variable & R Square \\
\hline Curiosity & 0.047 \\
\hline Purchase Intention & 0.117 \\
\hline
\end{tabular}

Table 3 Composite Reliability

Source: Researcher Processed Data (2020)

From the table above, the following conclusions can be drawn:

1. The Information Transparency variable affects the Curiosity variable by $4.7 \%$, while $95.3 \%$ is influenced by other variables.

2. The Curiosity variable affects the Purchase Intention variable by $11.7 \%$, while the remaining $88.3 \%$ is influenced by other variables.

\section{T-Statistics Test}

The t-test was conducted to see the significance level of the initial hypothesis of the study. The variable is stated to have a significant effect if it has a t-statistic value of $>$ 1.96. The following are the results of the t-statistic:

\begin{tabular}{|l|c|c|lr|}
\hline \multicolumn{1}{|c|}{ Influence } & $\begin{array}{c}\text { Path } \\
\text { Coefficient }\end{array}$ & T-Statistic & \multicolumn{2}{|c|}{ Information } \\
\hline $\begin{array}{l}\text { H1: Information Transparency } \rightarrow \\
\text { Curiosity }\end{array}$ & 0.217 & 2,431 & $\begin{array}{l}\text { Has a significant } \\
\text { effect }\end{array}$ \\
\hline $\begin{array}{l}\text { H2: Curiosity } \rightarrow \quad \text { Purchase } \\
\text { intention }\end{array}$ & 0.343 & 4,321 & $\begin{array}{l}\text { Has a significant } \\
\text { effect }\end{array}$ \\
\hline
\end{tabular}

Table 4 Statistical T-Test Results

Source: Researcher Processed Data (2020)

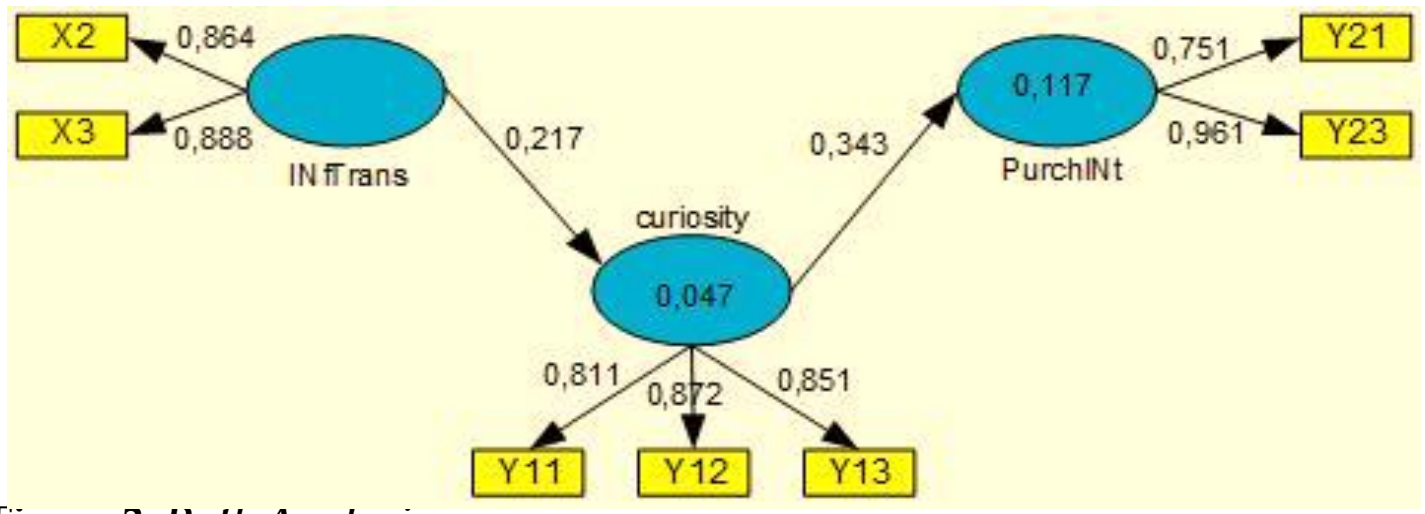

Figure 2. Path Analysis

Source: Researcher Processed Data

Based on the table above, it can be seen that the Path Coefficient is both positive and the t-statistic value is above 1.96. Therefore, it can be concluded that Information Transparency has a significant effect on Curiosity, hence hypothesis 1 is accepted. Likewise, Curiosity has a significant effect on Purchase Intention, hence hypothesis 2 is accepted. 


\section{CONCLUSIONS AND SUGGESTIONS \\ Effect of Information Transparency on Curiosity}

The results of existing research data show that Information Transparency has a significant effect on Curiosity. This means that Information Transparency is important for Curiosity to occur. The results of this study support previous research by Nunthiphatprueksa \& Suntrayuth (2018), which stated that the relationship between information from social media such as content and the quality of information transparency is considered more comprehensive and thus attract consumer curiosity. When viewed from the results of the descriptive analysis, the indicator with the highest value is online business actors providing reviews of their products. When consumers see product reviews, there will be a sense of curiosity to dig deeper into the product information which will affect consumer affection and cognition which later will have an impact on consumer purchasing decisions.

\section{The Effect of Curiosity on Purchase Intention}

The results of existing research data show that Curiosity also has a significant effect on Purchase Intention. The results of this study also support the results of previous research by Nunthiphatprueksa \& Suntrayuth (2018) in the context of tourism which stated that there is a significant relationship between curiosity and interest in tourists to visiting tourist destinations. In addition, Patanasiri and Krairit (2019) stated that there is a significant relationship between Curiosity and Purchase Intention. The results of these studies explained that the affective condition formed in a person through the received stimulus affects the consumer's psychology which then affects the consumer's buying interest.

Based on the results of descriptive analysis, the indicator with the highest value from the Curiosity variable is unclear information preventing consumers from trying new things. It is important for businesspeople to avoid providing such information on social media. If consumers see information that is unclear or doubtful, it is likely that consumers will be discouraged in trying the products offered. This fact is related to the indicators that are considered the most important for consumers related to the Purchase Intention variable, where the descriptive analysis results show that when curiosity exists, consumer exploratory interest increases, prompting consumers to find out more about the products offered before making a purchase.

Based on the explanation above, it is concluded that transparency of information and curiosity affect consumer buying interest in the spiku products of Comme company. The results of this study can provide insight and input to companies that use social media as a marketing tool for their products. Food and beverage business owners, especially those who rely on social media, can consider and take into account the quality and quantity of information that must be displayed in their business social media, in the hopes that transparency of information can increase consumers' curiosity about the products offered which will then lead to consumer buying interest.

For further research on consumer buying interest as a response, it is advisable to add variables related to Environmental Stimulus such as Information Overload or 
Social Overload. For the organism itself, variables such as Brand Image or those related to Customer Value can be examined.

\section{REFERENCE}

Abdillah, W., Hartono. (2015). Partial Least Square (PLS) Publisher Andi. Yogyakarta

Albaum, G. (1997). The Likert scale revisited: An alternate version. International Journal of Market Research, 39 (2), 331-348.

APJII. (2020). APJII 2019-2020 (Q2) Survey Report. Indonesian Internet Service Providers Association.

Çelik, S. (2017). The Usage of Instagram as a Marketing Tool. Journalism and Mass Communication, 7 (3). doi: 10.17265 / 2160-6579 / 2017.03 .002

Frambach, RT, Roest, HC, \& Krishnan, TV (2007). The impact of consumer Internet experience on channel preference and usage intentions across the different stages of the buying process. Journal of Interactive Marketing, 21 (2), 26-41. doi: 10.1002 / dir.20079

Ghozali, I., \& Fuad, F. (2014). Structural Equation Modeling: Theory, Concepts, and Applications with the Lisrel 9.10 Program (IV ed.). Semarang: Diponegoro University Publishing Agency.

Hair Jr., JF, Hult, GTM, Ringle, CM, \& Sarstedt, M. (2014). A primer on Partial Least Squares Structural Equation Modeling (PLS-SEM) United States of America: SAGE Publications Ltd.

Huey, LS, \& Yazdanifard, R. (2014). How Instagram can be used as a tool in social networking marketing. How Instagram Can Be Used as a Tool in Social Networking Marketing.

Hui, TX (2017). The Effect of source credibility on consumers' purchase intention in Malaysia online community. Journal of Arts and Social Sciences, 1 (1), 12-20.

Jackob, N., \& Hueß, C. (2015). Communication and Persuasion. Schlüsselwerke Der Medienwirkungsforschung, 49-60. doi: 10.1007 / 978-3-658-09923-7_5

Kashdan, TB, Stiksma, MC, Disabato, DD, McKnight, PE, Bekier, J., Kaji, J., \& Lazarus, R. (2018). The five-dimensional curiosity scale: Capturing the bandwidth of curiosity and identifying four unique subgroups of curious people. Journal of Research in Personality,

Ministry of Industry of Indonesia. (2019, February 18). The Food and Beverage Industry Becomes a Champion Sector [Press release]. Retrieved 2020, from https:/ / kemenperin.go.id/artikel/20298/Industri-Makanan-dan-Minuman-JadiSektor-Kampiun-

Kim, J., \& Lennon, SJ (2013). Effects of reputation and website quality on online consumers' emotion, perceived risk and purchase intention. Journal of Research in Interactive Marketing, 7 (1), 33-56. doi: 10.1108 / 17505931311316734

Kim, J., Song, H., \& Youn, H. (2020). The chain of effects from authenticity cues to purchase intention: The role of emotions and restaurant image. International Journal of Hospitality Management, 85, 102354.doi: 10.1016 / j.ijhm.2019.102354

Lee, YW, Strong, DM, Kahn, BK, \& Wang, RY (2002). AIMQ: A methodology for information quality assessment. Information \& Management, 40 (2), 133-146. doi: 10.1016 / s0378-7206 (02) 00043-5 
Mehrabian, A., \& Russell, JA (1974). The Basic Emotional Impact of Environments. Perceptual and Motor Skills, 38 (1), 283-301. doi: 10.2466 / pms.1974.38.1.283

Nunthiphatprueksa, A., \& Suntrayuth, S. (2018). The application of stimulus-organismresponse paradigm: the role of social media in Thailand's destination image and behavioral intentions. Asean Journal of Management and Innovation, 5 (1), 15-29. https:/ / doi.org/10.14456/ajmi.2018.2

Patanasiri, A., \& Krairit, D. (2019). A Comparative Study of Consumers' Purchase Intention on Different Internet Platforms. Mobile Networks and Applications, 24 (1), 145-159. https:/ / doi.org/10.1007/s11036-018-1139-3

Reio, TG (2019). Curiosity and interest. Human Resource Development Quarterly, 30 (4), 451-452. https://doi.org/10.1002/hrdq.21376

Voorveld, HA, Noort, GV, Muntinga, DG, \& Bronner, F. (2018). Engagement with Social Media and Social Media Advertising: The Differentiating Role of Platform Type. Journal of Advertising, 47 (1), 38-54. doi: 10.1080 / 00913367.2017.1405754

Wang, Z., \& Wang, N. (2012). Knowledge sharing, innovation and firm performanceZZ. Expertn Systems with Applications, 39 (10), 8899-8908. doi: 10.1016 / j.eswa.2012.02.017

Widodo, A., Yusiana, R., \& Aqmarina, FN (2019). Stimulus of Social Media; The Influence of E-WOM Towards Visiting Interest in the Lodge Maribaya Through Trust as Mediation Variable. SSRN Electronic Journal. doi: 10.2139 / ssrn.3353191

Williams, A. (2015). A global index of information transparency and accountability. Journal of Comparative Economics, 43 (3), 804-824. doi: 10.1016 / j.jce.2014.10.004

Xiang, Z., \& Gretzel, U. (2010). Role of social media in online travel information search.

Tourism Management, 31 (2), 179-188. doi: 10.1016 / j.tourman.2009.02.016

Zhou, L., Wang, W., Xu, J. (David), Liu, T., \& Gu, J. (2018). Perceived information transparency in B2C e-commerce: An empirical investigation. Information and Management, 55 (7), 912-927. https:// doi.org/10.1016/j.im.2018.04.005

Zhu, K. (2004). Information Transparency of Business-to-Business Electronic Markets: A Game-Theoretic Analysis. Management Science, 50 (5), 670-685. doi: 10.1287 / mnsc.1040.0226 